Department of Animal Genetics, Academy of Agriculture and Technology, Olsztyn, Poland

KRYSTYNA ŻYCZKO and GRAŻYNA MARIA ŻYCZKO

\title{
Relationship between transferrin and ceruloplasmin polymorphism and the frequency of diarrhoea in piglets
}

\begin{abstract}
Summary
The relationship between a phenotype of transferrin (Tf) and ceruloplasmin (Cp) and the frequency of diarrhoea occurrence was analysed in 317 piglets. It was observed that diarrhoea caused by haemolytic Escherichia coli strains including $\mathrm{K} 88 \mathrm{ab}$ and $\mathrm{K} 88$ ac occurred with greater frequency in piglets with phenotypes Tf $\mathrm{AB}$ and $\mathrm{Cp}$ $\mathrm{AB}$ than in piglets with phenotypes Tf $\mathrm{BB}$ and $\mathrm{Cp} \mathrm{BB}$. It is believed that polymorphic type of Tf $\mathrm{A}$ and $\mathrm{Cp} \mathrm{A}$ is related with piglets susceptibility to colibacteriosis which is caused by strains E. coli K88 ab and K88 ac.
\end{abstract}

Key words: diarrhoea, colibacteriosis, ceruloplasmin, transferrin, polymorphism, piglets.

\section{Zusammenfassung}

Titel der Arbeit: Beziehung zwischen dem Polymorphismus von Transferrin und Ceruloplasmin und der Durchfallhäufigkeit bei Ferkeln

Es wurden die Beziehungen zwischen dem Phänotyp von Transferrin (Tf) und Ceruloplasmin (Cp) bei 317 Hybridferkeln und der Durchfallhäufigkeit analysiert. Dabei konnte festgestellt werden, daß der von hämolythischen Stämmen von Escherichia coli, darunter auch von K88 ab und K88 ac hervorgerufene Durchfall viel häufiger bei Ferkeln mit den Phänotypen Tf $\mathrm{AB}$ sowie $\mathrm{Cp} \mathrm{AB}$ als bei Ferkeln mit den Phänotypen Tf $\mathrm{BB}$ und $\mathrm{Cp}$ BB auftrat. Es wird geschlußfolgert, daß der polymorphe Typ Tf A und Cp A mit der Anfäligkeit der Ferkel gegen Kolibakteriose zusammenhängt, die von den Stämmen E. coli K.88 ab und K.88 ac verursacht werden.

Schlüsselwörter: Durchfall, Kolibakteriose, Ceruloplasmin, Transferrin, Polymorphismus, Ferkel

\section{Introduction}

Diarrhoea occurring in piglets is mainly caused by pathogenic Escherichia coli strains. E. coli strains having antigen $\mathrm{K} 88$, also determined as $\mathrm{F}_{4}$, play a particularly significant role in their pathogenesis. These strains is the source of disease both in neonatal period and suckling and weaned as well (BERTSCHINGER, 1995).

E. coli K88 is found in three serological antigenic variants: K88 ab, K88ac and K88 ad (ORSKOV et al., 1964; GUINÉE and JANSEN, 1979). The presence of receptors for K88 fimbriae on enterocytes of epithelial cells of the small intestine in piglets enables the adherence of fimbriaic E. coli strains and their growth (MOON et al., 1979). As E. coli colonizes the small intestine and they have an ability to produce toxins they are regarded as the source of disease (SOJKA, 1971). SELLWOOD et al. (1975) showed that the occurrence of receptors for E. coli K88 ac on the surface of the small intestine conditions the susceptibility of piglets to diarrhoea. However, the lack of receptors causes their resistance. 
According to many authors the existence of receptors for K88 is coded by an autosomal dominant gene - S, whereas their lack is coded by a récessive allele - $\mathrm{s}$ (RUTTER et al., 1975; GIBBONS et al., 1977; SELLWOOD et al., 1975).

As the present research results show it is known that the receptors for antigens K88 ab and $\mathrm{K} 88$ ac are determined by dominant genes located in two closely linked loci (BONNEAU et al., 1990; GUÉRIN et al., 1993; EDFORS-LILJA et al., 1995; MARKLUND et al., 1996).

Genetic mechanism of inheritance of the receptor for $\mathrm{K} 88$ ad has not been fully explained so far (RAPACZ and HASLER-RAPACZ, 1986). EDFORS-LILJA et al. (1995) informed that the distance between loci of the genes coding the receptors for $\mathrm{K} 88 \mathrm{ab}$ and $\mathrm{K} 88$ ac was $1 \mathrm{cM}$. They also stated that there was also a strong link between loci: K88 abR and transferrin and ceruloplasmin, respectively: K88 abR and $\mathrm{Tf}-7,4 \mathrm{cM}$ and $\mathrm{Tf}$ and $\mathrm{Cp}-1,5 \mathrm{cM}$. The results of their research prove GIBBONS et al. (1977) suggestion who showed the existence of dependence between polymorphic types Tf and piglets susceptibility to diarrhoea caused by E. coli K88. The results obtained by GUÉRIN et al. (1993) correspond to them as well. Loci of the above discussed genes are located in 13 chromosome. The linkage map of this chromosome presented by MARKLUND et al. (1996) shows that the links between loci K88 abR, $\mathrm{K} 88 \mathrm{acR}$, Tf and $\mathrm{Cp}$ are even stronger than those given by EDFORS-LILJA et al. (1995). Passive protection of piglets by antibodies found in colostrum and milk of immunized sows is a commonly used method against colobacteriosis. It does not always bring satisfactory results. Possibility of applying polymorphic types of transferrin and ceruloplasmin as genetic resistance markers seems to be justified.

The aim of this research was to check if polymorphic types of transferrin and ceruloplasmin occurring in piglets can be factors differentiating the frequency of diarrhoea including these ones being caused by E. coli K88 ab and K88 ac.

\section{Material and Methods}

The research was carried out in the Plant of Swine Fattening. It included 317 piglets from 1 to 4 weeks old. The piglets came from 102 litters of hybrid sows: Polish Large White $x$ Polish Landrace. The following breeds were represented by boars $(n=17)$ : Duroc, Pietrain, Zlotnicka Spotted and hybrids of these breeds. Sows were immunized according to an instruction by NEOCOLIPOR vaccine (Rhone Merieux - France), containing E. coli strains with antigenes: $\mathrm{K} 88 \mathrm{ab}, \mathrm{K} 88 \mathrm{ac}, \mathrm{K} 88 \mathrm{ad}, \mathrm{K} 99,987 \mathrm{P}$. and $\mathrm{F}_{41}$. In blood serum obtained from piglets the type of transferrin (Tf) and ceruloplasmin (Cp) was determined by the method of electrophoresis in starch gel according to HESSELHOLT, 1969. Faeces ( $n=221$ samples) was taken from healthy piglets $(n=74)$ and from those with diarrhoea $(n=243)$. The samples with faeces underwent routine bacteriological examinations in order to determine E. coli strains (non - haemolytic and haemolytic). The examinations were carried out by Department of Veterinary Hygiene in Olsztyn. Identification of fimbrial antigens $\mathrm{K} 88 \mathrm{ab}$ and $\mathrm{K} 88 \mathrm{ac}$ was done according to the method given by OSEK and TRUSZCZYŃSKI, 1992. These examinations were 
carried out by Department of Microbiology at Veterinary Institute in Puławy. The obtained results underwent statistical analysis applying $\mathrm{chi}^{2}$ test.

\section{Results and Discussion}

Table 1 presents piglets characteristics comprising phenotypes in transferrin and ceruloplasmin systems and their state of health.

Table 1

Characteristic of piglets considering transferrin and ceruloplasmin phenotype and their health state (Charakteristik der Ferkel im Bezug auf den Phänotyp von Transferrin (Tf) und Ceruloplasmin (Cp) sowie auf ihren Gesundheitszustand)

\begin{tabular}{|c|c|c|c|c|c|c|c|c|c|c|}
\hline \multirow{3}{*}{$\begin{array}{l}\text { Pheno- } \\
\text { type of } \\
\text { piglets }\end{array}$} & \multicolumn{2}{|c|}{ Number } & \multicolumn{7}{|c|}{$\begin{array}{l}\begin{array}{c}\text { Frequency of occurrence and classification of diarrhoea cases in } \\
\text { piglets }\end{array} \\
\text { p }\end{array}$} & \multirow{3}{*}{$\begin{array}{c}\text { Piglets } \\
\text { without } \\
\text { diarrhoea } \\
\text { (bacteriolo- } \\
\text { gically } \\
\text { negative) }\end{array}$} \\
\hline & \multirow[t]{2}{*}{ piglets } & \multirow{2}{*}{$\begin{array}{c}\text { samples } \\
\text { of } \\
\text { faeces }\end{array}$} & \multicolumn{3}{|c|}{$\begin{array}{l}\text { E. coli strains including } \\
\qquad \mathrm{K} 88\end{array}$} & \multirow{2}{*}{$\begin{array}{l}\text { Citro- } \\
\text { bacter }\end{array}$} & \multirow{2}{*}{$\begin{array}{l}\text { Samples } \\
\text { negative }\end{array}$} & \multirow{2}{*}{$\begin{array}{l}\text { Non } \\
\text { exami- } \\
\text { ned }\end{array}$} & \multirow{2}{*}{ Total } & \\
\hline & & & $\mathrm{N}$ & $\mathrm{H}$ & K88 & & & & & \\
\hline \multicolumn{11}{|r|}{ negative) } \\
\hline AA & 48 & 37 & 15 & 12 & 4 & 1 & 6 & 9 & 43 & $5(3)$ \\
\hline $\mathrm{AB}$ & 152 & 112 & 47 & 38 & 24 & 4 & 17 & 27 & 133 & $19(6)$ \\
\hline $\mathrm{AC}$ & 3 & 1 & - & 1 & - & - & - & 1 & 2 & $1(-)$ \\
\hline BB & 108 & 66 & 30 & 9 & 2 & 1 & 15 & 6 & 61 & 47 (11) \\
\hline $\mathrm{BC}$ & 6 & 5 & 1 & - & - & - & 3 & - & 4 & $2(1)$ \\
\hline \multicolumn{11}{|l|}{ Cp: } \\
\hline$A B$ & 67 & 48 & 20 & 23 & 12 & - & 3 & 9 & 55 & $12(2)$ \\
\hline BB & 250 & 173 & 73 & 37 & 18 & 6 & 38 & 34 & 188 & $62(19)$ \\
\hline Total & 317 & 221 & 93 & 60 & 30 & 6 & 41 & 43 & 243 & $74(21)$ \\
\hline
\end{tabular}

Five phenotypes were observed in Tf system: AA, AB, AC, BB and BC. They were determined by alleles $-\mathrm{Tf}^{A}, \mathrm{Tf}^{\mathrm{B}}$ and $\mathrm{Tf}^{\mathrm{C}}$ with the following frequency, respectively: $\mathrm{Tf}^{\mathrm{A}}-0,396, \mathrm{Tf}^{\mathrm{B}}-0,590$ and $\mathrm{Tf}^{\mathrm{C}}-0.014$. Piglets $\mathrm{Tf} \mathrm{AB}(47,9 \%$ of the total number) and Tf $\mathrm{BB}(34,1 \%)$ were the most numerous. Fewer piglets Tf AA $(15,1 \%)$ and Tf BC $(2,0 \%)$ were found. Piglets with Tf AC phenotype (0.9\%) were observed sporadically. Phenotypes $\mathrm{Cp}$ AB and $\mathrm{Cp}$ BB occurred in Cp system. Phenotype $\mathrm{Cp}$ BB $(78,9 \%)$ was more popular than $\mathrm{Cp} \mathrm{AB}(21,1 \%)$. The frequency of alleles controlling this system was following: $\mathrm{Cp}^{\mathrm{A}}-0.106$ and $\mathrm{Cp}^{\mathrm{B}}-0.894$.

KURYŁ et al. (1996) report that in hybrids of generation $F_{2}$ obtained from crossbreeding of Polish Large White x Zlotnicka Spotted, phenotype Tf B $(67,5 \%)$ occurred twice as often as in comparison to $\operatorname{Tf} \mathrm{AB}(31,0 \%)$ and relatively rare - phenotype Tf $\mathrm{A}$ $(1,4 \%)$.

Among examined piglets (Table 1) phenotype $\mathrm{Tf} \mathrm{AB}$ dominated, however piglets $\mathrm{Tf}$ $\mathrm{BC}$ and Tf $\mathrm{AC}$ occurred as well. Participation of these phenotypes was insignificant (AC - 0,9 and BC - 2,0\%) in comparison to the observed ones by ŻURKOWSKI et al. (1974) in Zlotnicka Spotted pigs (Tf AC - 7,4 and Tf BC - 17,9\%). The authors also report that high frequency of alleles $\operatorname{Tf}^{C}(0,1280)$ is a particular feature of this breed 
which does not occur in Polish Large White and Polish Landrace and is very seldom in other breeds (ŻURKOWSKI et al., 1975).

Monomorphism is observed in the system $\mathrm{Cp}$ in the majority of breeds (HESSELHOLT, 1969). Zlotnicka Spotted breeds is contradiction because in this system polymorphism was found (ŻURKOWSKI et al., 1974; KURYŁ et al., 1996). KURYE et al. (1996) point out that phenotypes Cp F (8,3\%), Cp FS $(30,6 \%)$ and Cp S $(61,1 \%)$ are observed in Zlotnicka Spotted, in hybrids of Polish Large White $\mathrm{x}$ Zlotnicka Spotted three phenotypes occurred as well. The above presented results (Table 1) show that two phenotypes $\mathrm{Cp} A B$ and $\mathrm{Cp} B \mathrm{~B}$ were reported among the examined piglets. Allele $\mathrm{Cp}^{\mathrm{A}}$ could have been inherited from boars of Zlotnicka Spotted because as ŻURKOWSKI et al. (1975) report this allele does not occur in Polish Large White, Polish Landrace pigs and very seldom in other breeds.

The analysis of piglets health state shows that diarrhoea (in 76,5\%) was mainly caused by E. coli strains (Table 1). In case of 200 piglets with diarrhoea which faeces was examined bacteriologically, in 93 cases non-haemolytic E. coli strains caused diarrhoea, in 60 cases - haemolytic strains. Fimbriae K88 ab or K.88 ac were identified in $20 \%$ E. coli strains. Despite diarrhoea symptoms, the faeces samples taken from 41 piglets were bacteriologically negative, however the samples from 6 other piglets showed Citrobacter sp.

Table 2

Influence of transferrin and ceruloplasmin pl:cuotype in piglets on their health state (Einfluß des Phänotyps von Transferrin und Ceruloplasmin der Ferkel auf thren Gesundheitszustand)

\begin{tabular}{|c|c|c|c|c|}
\hline \multirow[t]{2}{*}{ Piglets phenotypes } & \multirow[t]{2}{*}{ Number of piglets } & \multicolumn{2}{|c|}{ Observed and expected number of piglets } & \multirow{2}{*}{$\begin{array}{c}\text { Value } \\
\text { chi }^{2}\end{array}$} \\
\hline & & with diarrhoea & healthy & \\
\hline \multicolumn{5}{|l|}{ Tf: } \\
\hline AA & 48 & $43(36,8)$ & $5(11,2)$ & $4,47^{x}$ \\
\hline $\mathrm{AB}$ & 152 & $133(116,5)$ & $19(35,5)$ & $10,01^{x x}$ \\
\hline $\mathrm{AC}$ & 3 & $2(2,3)$ & $1(0,7)$ & 0,16 \\
\hline BB & 108 & $61(82,8)$ & $47(25,2)$ & $24,59^{x x}$ \\
\hline $\mathrm{BC}$ & 6 & $4(4,6)$ & $2(1,4)$ & 0,33 \\
\hline Total & 317 & 243 & 74 & $39,56^{\times \times}$ \\
\hline \multicolumn{5}{|l|}{ Cp: } \\
\hline $\mathrm{AB}$ & 67 & $55(51,4)$ & $12(15,6)$ & 1,08 \\
\hline $\mathrm{BB}$ & 250 & $188(191,6)$ & $62(58,4)$ & 0,29 \\
\hline Total & 317 & 243 & 74 & 1,37 \\
\hline
\end{tabular}

${ }^{\mathrm{x}} \mathrm{P} \leq 0,05 ;{ }^{\mathrm{x}} \mathrm{P} \leq 0,01$

The influence of phenotypes of piglets in system Tf and $\mathrm{Cp}$ on their susceptibility to diarrhoea was present in Table 2 . The obtained results show that phenotype Tf of piglets influenced in a significant way their state of health. Diarrhoea was observed at higher frequency in piglets with phenotype $\mathrm{Tf} \mathrm{AB}$ and Tf $\mathrm{AA}$, whereas among healthy piglets there were found the ones with phenotype Tf BB. Differences in frequency of occurrence of diarrhoea cases in individuals being different of type $\mathrm{Tf}$ were statistically significant.

There was no significant dependence between piglets phenotype in $\mathrm{Cp}$ a system and 
their susceptibility to diarrhoea. Although more phenotype Cp BB were observed among healthy piglets and $\mathrm{Cp} \mathrm{AB}$ among ill ones.

Table 3

Characteristics of $\mathrm{E}$. coli strains decomposition in the faeces of piglets differentiated by $\mathrm{Tf}$ and $\mathrm{Cp}$ type (Charakteristik der Verteilung von E. coli - Stämmen, die im Exkrement der nach dem Typ von Tf und Cp differenzierten Ferkel vorhanden sind)

\begin{tabular}{|c|c|c|c|c|}
\hline \multirow[t]{2}{*}{ Piglets phenotype } & \multirow{2}{*}{$\begin{array}{c}\text { Percentage of } \\
\text { examined } \\
\text { samples of faeces }\end{array}$} & \multicolumn{3}{|c|}{$\begin{array}{l}\text { Observed and expected number of diarrhoea caused by E. col } \\
\text { strains: }\end{array}$} \\
\hline & & $\mathrm{N}$ & $\mathrm{H}$ & $\mathrm{K} 88$ \\
\hline \multicolumn{5}{|l|}{ Tf: } \\
\hline AA & 17,2 & $15(15,8)$ & $12(10,2)$ & $4(5,2)$ \\
\hline $\mathrm{AB}$ & 52,1 & $47(47,9)$ & $38(30,7)$ & $24(15,6)$ \\
\hline BB & 30,7 & $30(28,3)$ & $9(18,1)$ & $2(9,2)$ \\
\hline Total & 100,0 & 92 & 59 & 30 \\
\hline Value $x^{2}$ & & 0,07 & $6,67^{x}$ & $11,03^{x x}$ \\
\hline \multicolumn{5}{|l|}{ Cp: } \\
\hline $\mathrm{AB}$ & 21,7 & $20(20,2)$ & $23(13,0)$ & $12(6,5)$ \\
\hline BB & 78,3 & $73(72,8)$ & $37(47,0)$ & $18(23,5)$ \\
\hline Total & 100,0 & 93 & 60 & 30 \\
\hline Value $x^{2}$ & & 0,02 & $9,29^{x}$ & $5,38^{x}$ \\
\hline
\end{tabular}

Analysing the cases of colibacteriosis the piglets representing the most numerous phenotypes were taken into consideration: Tf $\mathrm{AA}$, Tf $\mathrm{AB}$ and $\mathrm{Tf} \mathrm{BB}$, neglecting less numerous Tf AC and Tf BC. The data presented in Table 3 show that diarrhoea caused by non-haemolytic E. coli strains with similar frequency occurred among piglets with a different phenotype determined both in system Tf as well in system $\mathrm{Cp}$. The cases of its occurrence were proportional to the number of samples of faeces taken from piglets Tf: $\mathrm{AA}, \mathrm{AB}, \mathrm{BB}$ and $\mathrm{Cp} \mathrm{AB}$ and $\mathrm{Cp} \mathrm{BB}$. Diarrhoea which was caused by haemolytic E. coli strains was mostly determined by piglets phenotypes. More cases of diarrhoea were found in piglets with phenotypes $\mathrm{Tf} A B$ and $\mathrm{Tf} A \mathrm{~A}$, whereas in piglets with phenotype Tf BB it occurred more seldom than it had been expected. These deviations were statistically significant.

Statistically significant deviations occurred too between the number of the observed cases of diarrhoea among piglets having different $\mathrm{Cp}$ type and the expected number. Piglets $\mathrm{Cp} \mathrm{BB}$ where diarrhoea was caused by haemolytic E. coli strains were very few but in piglets with $\mathrm{Cp} \mathrm{AB}$ phenotype diarrhoea occurred more frequently.

The analysis of cases of diarrhoea caused by fimbrial E. coli showed that in 22 piglets it was caused by fimbriae K88 ac whereas in 8 by K88 ab. Registered number of piglets with diarrhoea which differed by the Tf and $\mathrm{Cp}$ types showed significant deviations with the expected number (resp. statistically highly significant and significant). Significantly more piglets with $\mathrm{Tf} A B$ and $\mathrm{Cp} A \mathrm{AB}$ phenotypes showed greater susceptibility to this disease factor in comparison to piglets $\mathrm{Tf} \mathrm{BB}$ and $\mathrm{Cp} \mathrm{BB}$. The obtained results partly correspond to the results presented dy GIBBONS et al. (1977). They stated that susceptibility of piglets to diarrhoea caused by E. coli strains 
K88 should be related to Tf $\mathrm{AB}$ phenotype, resistance with $\mathrm{Tf} \mathrm{BB}$ phenotype. This feature was suggested as existence of the link between allele $\mathrm{Tf}^{A}$ and gene $\mathrm{S}$ coding the occurrence of receptors for E. coli K88 on the surface of the small intestine. The presented data (Table 3 ) show that diarrhoea caused by fimbrial E. coli strains mostly occur in piglets $\mathrm{Tf} A B$ but significantly less frequently in piglets Tf $\mathrm{BB}$. Probably in the examined piglets both allele $\mathrm{Tf}^{\wedge}$ and $\mathrm{Cp}^{\wedge}$ were linked with genes conditioning the existence of receptors. The observed relationship between allele $\mathrm{Tf}^{\mathrm{A}}$ and in smaller degree $\mathrm{Cp}^{\mathrm{A}}$ (because of its lack or lower frequency in pigs in majority of breeds) and genetically conditioned predisposition to the occurrence of diarrhoea caused by E.coli K88 may have a practical application. Polymorphism of transferrin may serve as an index used while choosing couples for reproduction. It is proved by the fact that a susceptible offspring, resistant sows and susceptible boars according to SELLWOOD (1979) is particularly susceptible to diarrhoea. Colostrum of resistant sows even after their immunization shows a low level of antibodies for E. coli K88 and it does not protect their susceptible piglets against infection (SELLWOOD, 1979). Colostrum of susceptible sows by higher antiadhesive and opsonic activities than resistant sows inhibits the binding antigen K88 to brush borders of the intestine in piglets (SELLWOOD, 1982).

JOVANOVIC et al., 1996 state that genetic polymorphic conditioning the resistance to colibacteriosis K88 occur among the majority of breeds. It causes the necessity for carrying out selection in order to decrease the cases of this disease. BAKER et al. (1997) observed that the occurrence of non-adhesive phenotypes for E. coli K88 in pigs, characteristic for resistant individuals, showed different frequency depending on the breed.

According to JOVANOVIC et al. (1996) the existence of both susceptible and resistant pigs to colibacteriosis in herd causes necessity of identification of resistant genotypes which can be carried out by using biochemical markers. This identification should concern first of all boars especially those which are used for industrial cross-breeding.

\section{Conclusion}

The obtained results help in formulating the following statements:

Phenotype differentation in piglets occurring in transferrin and ceruloplasmin systems was related to their susceptibility to diarrhoea. This regularity was observed especially in case of diarrhoea caused by haemolytic E. coli strains including K88 ab and K88 ac. Diarrhoea occurred in greater number of piglets with phenotypes $\mathrm{Tf} A B$ and $\mathrm{Cp} A B$ than in piglets with phenotypes Tf BB and $\mathrm{Cp}$ BB. It is believed that polymorphic type TfA and Cp A predisposes piglets to susceptibility to diarrhoea which is caused by $\mathrm{E}$. coli K88ab and K88 ac.

\section{References}

BAKER, D. R.; BILLEY, L. O.; FRANCIS, D. H.:

Distribution of K88 Escherichia coli-adhesive and nonadhesive phenotypes among pigs of four breeds. Vet. Microbiol. 54 (1997), 123-132 
BERTSCHINGER, H. U.:

Pathogenesis of porcine post-weaning Escherichia coli diarrhoea and oedema disease. Pigs News and Information 16 (1995), 85-88N

BONNEAU, M.; DUVAL-IFLAH, Y.; GUERIN, G.; OLLIVIER, L; RENARD, C.; RENJIFO, X.; Aspects génétique et microbiologiques de la colibacillose K88 chez le porc. Annales de Recherches Vétérinaires. 21 (1990), 302-3

EDFORS-LILJA, I.; GUSTAFSSON, U.; DUVAL-IFLAH, Y.; ELLERGREN, H.; JOHANSSON, M.; JUNEJA, R. K.; MARKLUND, L.; ANDERSSON, L.:

The porcine intestinal receptor for Escherichia coli $\mathrm{K} 88$ ab, K88 ac: regional localization on chromosome 13 and influence of IgG response to K88 antigen. Animal Genetics 26 (1995), 237-242

GIBBONS, R. A.; SELLWOOD, R.; BURROWS, M.; HUNTER, P. A.:

Inheritance of resistance to neonatal E. coli diarrhoea in the pig: examination of genetic system. Theor. Appl. Genet. 51 (1977), 65-70

GUERRIN, G.; DUVAL-IFLAH, Y.; BONNEAU, M.; BERTAUD, M; GUILLAUME, P.; OLLIVIER, L.: Evidence for linkage between K88 ab, K88 ac intestinal receptors to Escherichia coli and transferrin loci in pigs. Animal Genetics 24 (1993), 393-396

GUINÉE, P. A. M.; JANSEN, W. H.:

Behaviour of Escherichia coli $\mathrm{K}$ antigens $\mathrm{K} 88 \mathrm{ab}, \mathrm{K} 88 \mathrm{ac}$ and $\mathrm{K} 88 \mathrm{ad}$ in Immunoelectrophoresis, double diffusion and hemagglutination. Infect. Immun. 23 (1979), 700-705

HESSELHOLT, M.:

Serum protein polymorphisms in swine. Electrophoretic, identification, Genetic and application. Munksgaard. Copenhagen. (1969)

JOVANOVIČ, S.; TRAILOVIČ, R.; GAGRCIN, M.; SARAČ, M.; SAVIČ, M.:

Genetic aspects of resistance of pigs to E.coli infection. (Polish Language).Vet. Glasnik. 50 (1996), $65-$ 68

KURYŁ, J.; ŻURKOWSKI, M.; RÓZZYCKI, M.; KAMYCZEK, M.; JANIK, A.; DUNIEC, M.; KORWINKOSSAKOWSKA, A.; PIERZCHA£A, M.; NIEMCZEWSKI, C., CZERWIŃSKI, S.:

The Polish "Pig genome mapping" project. II Characterization of the genetic structure of generation $\mathrm{F}_{2}$ on the basis of genetic markers. Animal Science Papers and Reports 14 (1996), 199-206

MARKLUND, L.; JOHANSSON MOLLER, M.; HOYHEIM, B.; DAVIES, W.; FREDHOLM, M.; JUNEJA, R.

K.; MARIANI, P.; COPPIETERS, W.; ELLEGREN, H.; ANDERSSON, L.:

A comprehensive linkage map of the pig based on a wild pig - Large White intercross. Animal Genetics 27 (1996), 255-269

MOON, H.W.; ISAACSON, R. H.; POHLENZ, J.:

Mechanisms of association of enteropatogenic Escherichia coli with intestinal epithelium. Am. J. Clin. Nutr. 32 (1979), 119-127

ORSKOV, I.; ORSKOV, F.; SOJKA, W. J.; WITTING, W.:

K antigens K88 ab (L) and K88 ac (L) in Escherichia coli. Acta Pathol. Microbiol. Scand. 62 (1964), 439-447

OSEK, J.; TRUSZCZYŃSKI, M.:

Occurrence of fimbriae and enterotoxins in Escherichia coli strains isolated from piglets in Poland. Comp. Immunol. Microbiol. Infect. Dis. 15 (1992), 285-292

RAPACZ, J.; HASLER-RAPACZ, J.:

Polymorphism and inheritance of swine small intestinal receptors mediating adhesion of three serological variants of Escherichia coli producing K88 pilus antigen. Animal Genetics 17 (1986), 305 321

RUTTER, J. M.; BURROWS, M. R.; SELLWOOD, R.; GIBBONS, R. A.: A genetic basis for resistance to enteric disease caused by E. coli. Nature, London 257 (1975), 135-136

SELLWOOD, R.:

Escherichia coli diarrhoea in pigs with and without the K88 receptor. Vet. Rec. 105 (1979), 228-230

SELLWOOD, R:

Escherichia coli associated porcine neonatal diarrhoea: antibacterial activities of colostrum from genetically susceptible and resistant sows. Infect. Immun. 35 (1982), 396-401

SELLWOOD, R.; GIBBONS, R. A.; JONES, G. W.; RUTTER, J. M.:

Adhesion of enteropathogenic Escherichia coli to pig intestinal brush borders: the existence of two pig phenotypes. J. Med. Microbiol. 8 (1975), 405-411 
SOJKA, W. J.:

Enteric diseases in new born piglets, calves and lambs due to Escherichia coli infection. Vet. Bull. 41 (1971), 509-522

ŻURKOWSKI, M.; TOMASZEWSKA-GUSZKIEWICZ, K.; KLUCIŃSKI, W.

Serum proteins polymorphism in Złotnicka pig. Genetica Polonica 15 (1974), 119-123

ŻURKOWSKI, M.; KLUCIŃSKI, W.; MICHALAK, W.:

The polymorphism of proteins of blood plasma in pigs of the Polish Large White and Polish Landrace breeds. (Polish Language). Prace i Materiały Zootechniczne 8 (1975), 23-29

Received: 11.11 .1997

Accepted: 15.12 .1998

Authors address

Dr. hab., prof. ART KRYSTYNA ŻYCZKO

Mgr GRAZZNA MARLA ŻYCZKO

Academy or Agriculture and Technology

Department of Animal Genetics

10-957 Olsztyn

Oczapowskiego 5/115

POLAND 